\title{
Dietary Nutrients, Proteomes, and Adhesion of Probiotic Lactobacilli to Mucin and Host Epithelial Cells
}

\author{
Hasan Ufuk Celebioglu ${ }^{1}$ and Birte Svensson ${ }^{2, *(D)}$ \\ 1 Department of Biotechnology, Bartin University, 74110 Bartin, Turkey; ufukcelebioglu@gmail.com \\ 2 Department of Biotechnology and Biomedicine, Technical University of Denmark, \\ DK-2800 Kgs Lyngby, Denmark \\ * Correspondence: bis@bio.dtu.dk; Tel.: +45-45-25-27-40
}

Received: 15 June 2018; Accepted: 14 August 2018; Published: 21 August 2018

\begin{abstract}
The key role of diet and environment in human health receives increasing attention. Thus functional foods, probiotics, prebiotics, and synbiotics with beneficial effects on health and ability to prevent diseases are in focus. The efficacy of probiotic bacteria has been connected with their adherence to the host epithelium and residence in the gut. Several in vitro techniques are available for analyzing bacterial interactions with mucin and intestinal cells, simulating adhesion to the host in vivo. Proteomics has monitored and identified proteins of probiotic bacteria showing differential abundance elicited in vitro by exposure to food components, including potential prebiotics (e.g., certain carbohydrates, and plant polyphenols). While adhesion of probiotic bacteria influenced by various environmental factors relevant to the gastrointestinal tract has been measured previously, this was rarely correlated with changes in the bacterial proteome induced by dietary nutrients. The present mini-review deals with effects of selected emerging prebiotics, food components and ingredients on the adhesion of probiotic lactobacilli to mucin and gut epithelial cells and concomitant abundancy changes of specific bacterial proteins. Applying this in vitro synbiotics-like approach enabled identification of moonlighting and other surface-located proteins of Lactobacillus acidophilus NCFM that are possibly associated with the adhesive mechanism.
\end{abstract}

Keywords: lactobacilli; probiotics; adhesion; mucin; intestinal cells; carbon sources; polyphenols; surface proteomes; protein identification; moonlighting proteins

\section{Introduction}

Diet and its effects on the microbiota of the gastrointestinal tract (GIT) are of paramount importance for human health through influence on the immune system, and hence allergies, diabetes, bowel disorders, and cancers. Such an increasingly recognized role of food components may eventually invoke suggestions to counteract the adverse effects of inappropriate dietary regimes and risks to develop various illnesses. Awareness has thus improved, especially in the past decade, on consumption of functional foods and beverages with possible favorable impact on health via insights into the gut microbiota and microbiome [1-4]. This includes attention on conventional or everyday foods as part of a normal diet that contains natural compounds proven in scientific and clinical studies to exert positive effects on health beyond a mere nutritional value. The present mini-review focuses on molecular insights at the bacterial proteome level characterizing interactions of lactobacilli, dietary components, mucin, and host epithelial cells with specific emphasis on factors important in GIT adhesion [5-8] that may eventually be managed by food choices. 


\section{Gastrointestinal Tract, Mucins, and Lactobacilli}

\subsection{Mucosa and Mucins}

The GIT is home to microorganisms and a major location for innate and acquired immunity [9-13]. It is covered by mucus that accommodates the majority of the microbiota and is the place for the attachment of bacteria, being either probiotic, commensal or pathogenic, and intimate encounters with the host. The mucus (Figure 1) is a gel layer serving for hydration and lubrication as well as a barrier against pathogens and harmful substances [14-16]. It consists mostly of water, glycoproteins, salts, and lipids. Mucins are large extracellular proteins, which are heavily glycosylated (about $80 \%$ of the mass) carrying numerous oligosaccharide decorations of DP 4-15 and providing viscosity and gelling properties $[14,17,18]$. The protein moieties of mucins possess (i) a central glycosylated region composed of sequence repeats rich in serine, threonine, and proline, (ii) $\mathrm{N}$ - and C-terminal regions of globular-like structure with relatively low glycosylation, and iii) cysteine-rich domains engaged in disulfide mediated dimerization and polymerization (Figure 1) $[14,17,19]$.

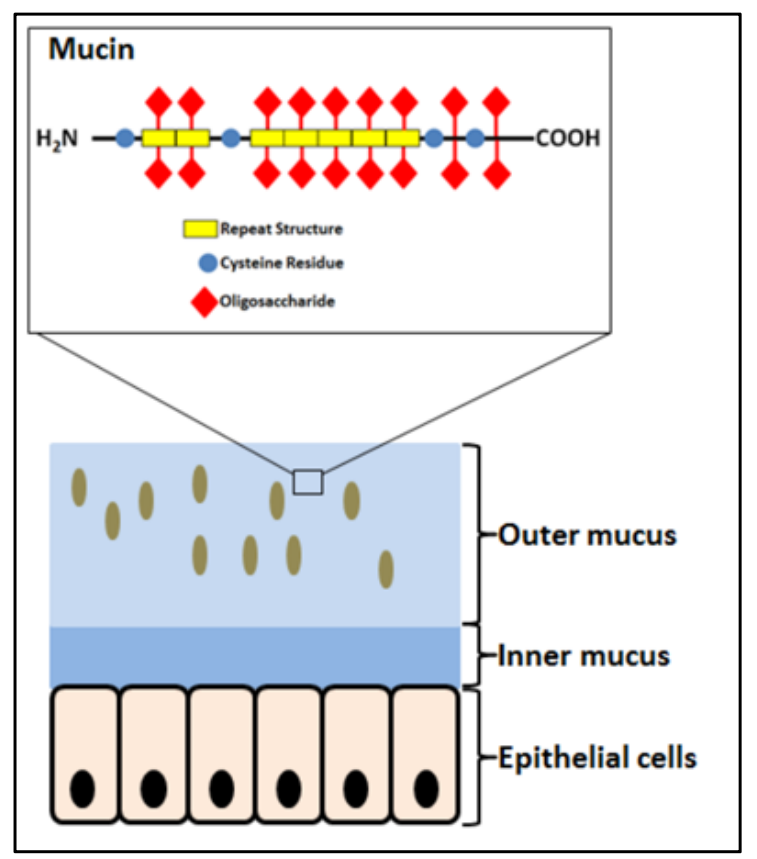

Figure 1. Schematics of the mucosa covering the gastrointestinal tract and the structure of mucin, the glycoprotein component of the mucus layer. Brown ovals illustrate bacteria. Modified from Reference [17].

\subsection{Probiotic Lactobacilli}

Lactobacilli are non-spore forming, Gram-positive, non-motile, rod-shaped bacteria varying in length and important members of a normal human microbiota [4,20]. Generally, lactobacilli are facultative anaerobes and able to grow in anaerobic and aerobic environments, producing lactic acid as end product of glucose fermentation [21]. The human GIT is colonized by several Lactobacillus species, including Lactobacillus acidophilus, L. brevis, L. casei, L. fermentum, L. gasseri, L. johnsonii, L. paracasei, L. plantarum, L. rhamnosus, and L. salivarius $[22,23]$. Some lactobacilli have been approved as probiotics defined by the FAO/WHO as "live microorganisms that, when administered in adequate amounts, confer a health benefit on the host" [24]. This distinguishes the live microorganisms directly applied for gaining favorable health effects from those used in processing of foods or production of various compounds $[22,25,26]$. The probiotic status requires that the bacterial species or strain is associated with two general host health benefits, namely support of (i) a healthy digestive tract and (ii) a healthy 
immune system (Figure 2) [24]. Other criteria for a probiotic bacterium include being safe (i.e., no gene transfer to or from other species or production of toxins), to survive through the GIT and adhere effectively to the mucosa, be viable during storage and use, be isolated from a human source, and have good sensory abilities [4,26-28].

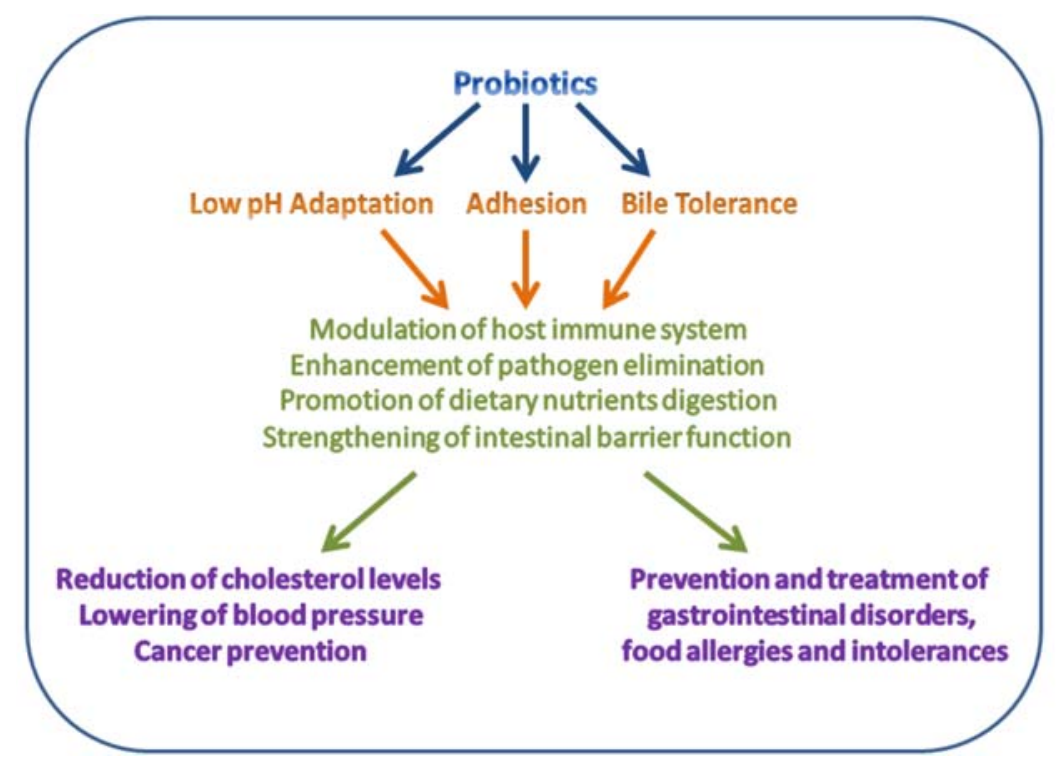

Figure 2. Some beneficial effects of probiotics to human health. Modified from Reference [29].

Lactobacilli can exert health benefits in several ways, for example by inhibiting growth of pathogenic bacteria as they produce lactic, propionic, and acetic acids lowering the $\mathrm{pH}$ that suppresses proliferation of pathogens in the GIT [20,30,31]. Additionally, they can competitively prevent attachment of pathogens to the epithelium [16,32-35]. Lactobacilli have also been connected with improvements of gut diseases or disease-associated symptoms. Several studies thus reported that some lactobacilli can be successful in treating irritable bowel syndrome [3,4,36,37]. Different lactobacilli, either alone or in combination with other probiotics (e.g., bifidobacteria) have improved antibiotic-associated diarrhea [4,38]. Also, profiling of the crosstalk between bacteria and intestinal cells at the molecular level is getting increasing attention [39].

\section{Lactobacillus Subproteome Analyses}

The characteristics of protein profiles of probiotic bacteria with relevance for adhesion have been explored by applying proteomic approaches involving in silico as well as experimental procedures for identification and quantification of surface-exposed and secreted proteins [40-42]. Notably, experimental protocols are established dedicated to analysis of the surface subproteome and the secretome (exoproteome), respectively, both of which are of particular interest when describing the bacteria-host molecular interactions in adhesion processes. Surface proteins have thus been isolated from L. acidophilus NCFM and other lactobacilli by lithium chloride or guanidine hydrochloride treatment and identified by liquid chromatography and mass spectrometry (LC-MS) or by 2-dimensional electrophoresis (2-DE) and mass spectrometry [10,40,42-47]. Several L. acidophilus proteins including the surface layer protein SlpA have been identified as potential adhesive molecules by proteome analysis using 2-DE and mass spectrometry $[42,44,45]$ and by comparison of strains with high and low adhesive capacity to Caco-2 intestinal cells [43]. Proteins involved in adhesion have also been monitored by analyzing subproteomes using western blotting [48]. 


\section{Adhesion Factors of Lactobacilli}

\subsection{Assaying Bacterial Adhesion In Vitro}

Adherence of beneficial bacteria to the intestinal mucosa is considered important for exerting their function and is a claimed key characteristic of probiotics $[5,15,28,49,50]$. In vitro studies thus commonly analyze adherence of probiotic bacteria to i) mucin adsorbed onto abiotic surfaces (e.g., polystyrene), ii) confluent intestinal cell layer cultures (HT-29, HT-29-MTX and Caco-2 are customary cell lines used in adhesion assays) in cell/tissue culture plates, or iii) extracellular matrix components such as fibronectin and collagen $[7,15,49,51-53]$ (Figure 3). Although these commonly applied cell lines are obtained from colonic carcinoma they express many of the markers associated with normal small intestine villus cells, including a diverse ability to produce or not produce mucin proteins $[7,52,53]$.

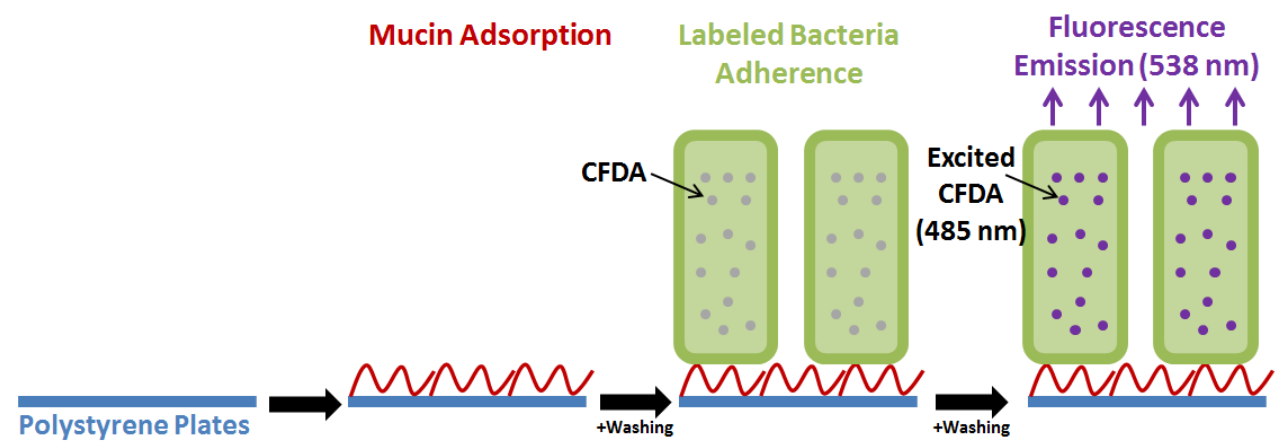

Figure 3. Mucin is adsorbed (or HT-29 cells are grown) onto polystyrene plates and added Lactobacillus acidophilus NCFM (OD at $600 \mathrm{~nm}=0.5$ ) labeled with carboxyfluorescein diacetate (CFDA). Following washing, the remaining fluorescence is determined after bacterial cell lysis as a measure of the amount of adhered bacteria [44,51].

Bacterial molecular factors that stimulate adhesion have been identified at the genome and proteome levels by comparing strains showing different adhesive capacity [43,54]. Subsequent validation can involve gene knock-out or overexpression, but methods relying on (i) depletion or shaving of proteins situated on the bacterial surface, (ii) effects in adhesion assays by competition with recombinantly produced proteins, or (iii) competition amongst bacteria for elimination of pathogens, also received broad interest $[8,10,23,34,44-47,55]$.

Bacterial adhesion processes can be mediated by physico-chemical forces such as hydrophobic and electrostatic interactions via lipoteichoic acids or surface proteins $[5,15,50]$. Hydrophobicity is evaluated by mixing the bacterial culture with organic solvents and measuring the contents of bacteria in the aqueous phase spectrophotometrically at $600 \mathrm{~nm}$ before and after the solvent addition [56]. It has been suggested to apply hydrophobicity analysis as a screening tool in evaluating adhesion potential of probiotic bacteria [33,57]. Also bacterial aggregation has been connected with the adhesive ability [50] and claimed a desirable characteristic of probiotics, since aggregated bacteria inhibited adhesion of pathogenic bacteria [58]. Although this phenomenon is complex and the precise mechanism is unclear, aggregation-promoting proteins on the surface of bacteria were noted to be important. For example, deletion of an aggregation-promoting factor of L. acidophilus NCFM (LBA0493) reduced adhesion to Caco- 2 cells, mucin, and the extracellular matrix components fibronectin, collagen IV, and laminin, even though the morphology of the bacterial cells was not altered [59]. 


\subsection{Identification of Surface Proteins in Lactobacillus acidophilus NCFM}

Not surprisingly, lactobacilli were reported to adhere to mucin and intestinal cells through their surface-associated proteins $[7,11,47,59,60]$. Thus, previously several surface proteins were identified to be involved in adhesion of lactobacilli and the findings were in some cases validated by using genetic tools, typically gene knock-out/suppression or overexpression [10,11,44,47,54,59,60]. Importantly, the growth state (e.g., logarithmic versus stationary phase) is connected with distinct surface-layer associated proteome differences [40]. This fact is significant as in vitro analyses for comparative effects on proteins in surface and extracellular proteomes with roles in adhesion should be done at a relevant growth stage. Also both environmental conditions $(\mathrm{pH}$, bile) and carbon sources or additives (refer to Section 6), are important [61].

A prominent group of surface proteins in lactobacilli with a role in adhesion are mucus-binding proteins (MUBs) [15,17,19]. Their structures include repeated domains, called MucBP repeats, suggested to establish microbe-host interactions; MucBP containing proteins have been claimed to promote the evolution of lactobacilli to be primary gut microorganisms $[15,17,62,63]$. Other key factors are the surface layer protein (Slp), which is one of the dominant proteins in lactobacilli, and the surface-layer associated proteins (Slaps), forming a self-assembled paracrystalline monolayer that covers all of the bacterial surface $[10,11,40,47]$. Inactivation of the protein SlpA by gene knock-out in L. acidophilus NCFM decreased adhesion to Caco- 2 cells by $84 \%$ compared to wild type [7]. Furthermore, insertional gene inactivation of fibronectin-binding protein A (LBA1148) and mucin-binding protein (LBA1392) decreased the adhesion of L. acidophilus NCFM by 76\% and 65\%, respectively [7]. Deletion of another L. acidophilus NCFM fibronectin-binding protein (FbpB, LBA0191) decreased adhesion to mucin and fibronectin by $47 \%$ and $72 \%$, respectively [60]. The deletion of the serine protease homologue Prtx caused increased autoaggregation, and the $\Delta p r t x$ strain showed $40 \%$ and $20 \%$ increased adhesion to mucin and fibronectin, respectively, compared to the parent [10]. Prtx likely impacts how proteins are displayed on the bacterial cell surface and may alter the structure and properties of the epithelial cell matrix. Notably, L. acidophilus NCFM $\Delta$ prtx improved the GIT epithelial barrier integrity in germ-free mice [10]. Overall, the general understanding is that multiple surface-associated bacterial proteins serve to adhere to mucin and intestinal cells.

Thermostable pullulanase from Streptococcus pyogenes binds to glycoproteins including submaxillary mucin and has a role in adhesion to epithelial cells, although its canonical function is to catalyze hydrolysis of $\alpha$-1,6-glucosidic linkages in glycogen, amylopectin and pullulan [64,65]. Thus, a potential role in adhesion was confirmed for thermostable pullulanase from L. acidophilus NCFM by a pullulanase-deficient mutant ( $\triangle$ lba1710) causing $35 \%$ less adhesion to mucin than the wild type (Figure 4) [44]. In a different approach, the moonlighting L. acidophilus NCFM elongation factor $\mathrm{G}$ and pyruvate kinase, showing increased abundancy in the surface proteome when grown on raffinose, cellobiose, and glucose supplemented with either mucin or resveratrol (Table 1), were produced recombinantly and pre-incubated with a mucin layer, which reduced the bacterial adhesion by $8-13 \%$ [45]. Moonlighting proteins will be described in more detail below (refer to Section 4.4). 

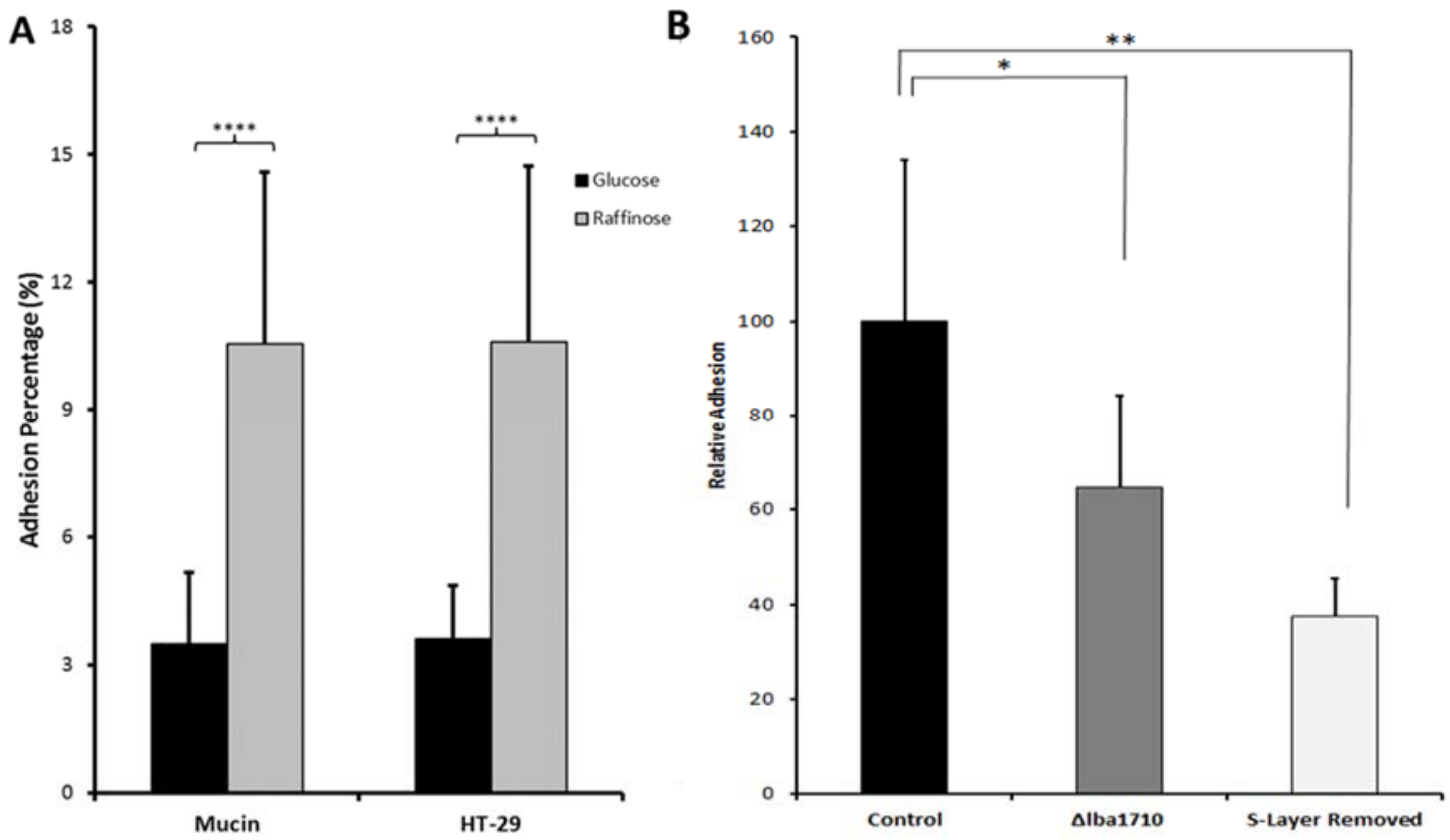

Figure 4. In vitro adhesion of Lactobacillus acidophilus NCFM to mucin and HT-29 cells. (A). Bacteria grown with glucose (black) and raffinose (grey). (B). Adsorption to mucin of wild type grown on raffinose (black), a thermostable pullulanase deletion mutant ( $\Delta$ lba1710) (grey), and surface depleted wild type (white). Modified from Reference [44].

Furthermore, by using bioinformatics in silico analysis myosin cross-reactive antigen (LBA0649) and cell division protein A (LBA0223) have been assigned roles in adhesion of L. acidophilus NCFM to Caco- 2 cells as demonstrated by corresponding insertional gene disruptions that caused 50 and $45 \%$ reduced adhesion for exponential and stationary phase cultures, respectively [8].

\subsection{Some Adhesive Surface Proteins Identified in Other Probiotic Lactobacilli}

In L. rhamnosus GG the SpaCBA pili protein was found to be important for adhesion and might confer prolonged GIT retention. This was supported by lack of adherence to Caco-2 cells of a non-piliated L. rhamnosus GR-1 strain as well as by a SpaCBA knock-out of L. rhamnosus GG [54]. In L. rhamnosus FSMM22 several anchorless surface proteins have been identified as laminin-adhesins, including known moonlighting proteins as well as ribosomal proteins [66] (refer to Section 4.4). Notably, on the host side, screening a Toll-like receptor-derived peptide library for improved adhesion of L. rhamnosus GG identified an octapeptide mediating enhanced adhesion to Caco-2 cells [67]. Indeed the interaction between bacteria and the host mucosa is gaining attention including analysis of effects at the molecular level reported by proteome analysis of co-cultures [39].

\subsection{Identification of Moonlighting Proteins in Probiotic Lactobacilli}

Besides pili proteins, which are situated on the bacterial surface and have a canonical function in cell-cell and cell-extracellular matrix protein interactions, lactic acid bacteria contain a large number of proteins referred to as moonlighting proteins, which have been demonstrated to act in adhesion [16,66,68] (Figure 5). Moonlighting proteins are multifunctional proteins that participate in unrelated biological processes and which are not the result of gene fusion. They are anchorless and the mechanism of the export to the surface has not been identified, but it was proposed to occur eitherby non-canonical secretion, as these proteins lack a signal motif, or by binding of cytosolic proteins from lysed cells onto the cell wall of intact bacteria, although this latter mechanism recently received reduced support [5,61,68-70]. Moonlighting proteins comprise a subset of multifunctional proteins belonging 
to different categories, metabolic enzymes, molecular chaperones, translational elongation factors, ribosomal and other proteins [16,29,50,66,68,69,71]. Following simulated GIT passage by exposure to bile and acidic $\mathrm{pH}$, L. paracasei CIDCA 83123 showed clearly increased capacity to adhere to mucin and Caco- 2 cells. The proteome analysis indicated differentially abundant proteins, which increased by 1.4-4.3 fold, some of which were moonlighting proteins, glyceraldehyde-3-phosphate dehydrogenase (GADPH, two forms), L-lactate dehydrogenase, phosphoglyceromutase and UTP-glucose-1-phosphate uridyltransferase, while cell wall hydrolase, amylase family (two forms), surface antigen (two forms), a GADPH form, protein lacX, and galactose mutarotase-like protein decreased by 2-8 fold [61]. Notably, also GADPH of L. acidophilus NCFM binds to host mucin [55].

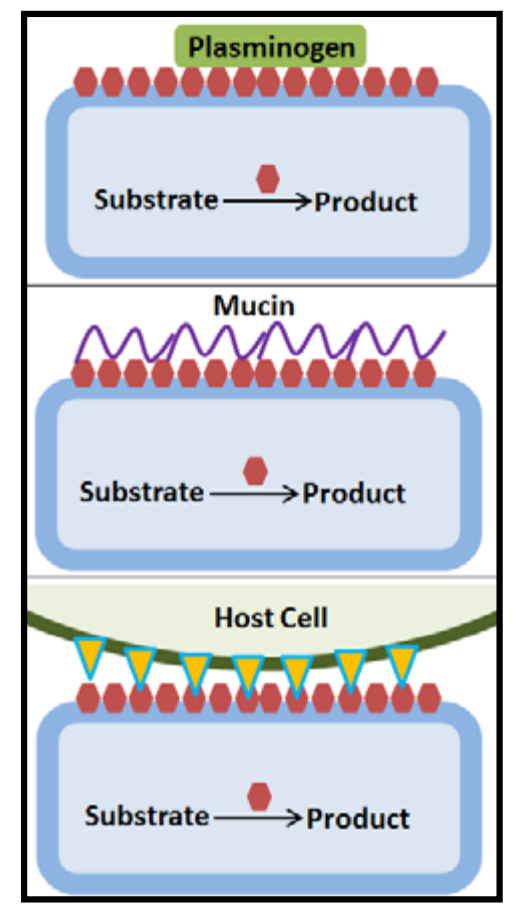

Figure 5. Moonlighting proteins (red hexagonals) have multiple functions, the main function for example being as housekeeping enzymes in the intracellular metabolism. The secretion mechanism to the cell surface where moonlighting proteins can act with roles in adhesion to proteins of the extracellular matrix or plasminogen, glycoproteins of the mucin layer or host cell surface proteins has not been elucidated [55,61,68-70].

The probiotic strain L. plantarum KLDS1.0391 isolated from fermented dairy products has 293 genes encoding cell wall proteins. Fifty-two of the proteins are predicted to be potentially surface exposed, some of which have a confirmed role in adhesion, e.g. the moonlighting triose phosphate isomerase, elongation factor Tu, glyceraldehyde-3-phosphate dehydrogenase, three mucus binding proteins and three fibronectin-binding proteins [72]. Further, GADPH and triose phosphate isomerase were reported in L. plantarum 423 to play a role in adhesion and competitive exclusion of pathogens [73]. The effects of several moonlighting proteins, molecular chaperone proteins and other adhesion-related proteins have been confirmed, for example for S-layer proteins in L. helveticus strain T159 [50]. 


\section{Effect of Compounds in the Diet on Adhesion of Lactobacilli}

\subsection{Prebiotics}

The term "prebiotics" was introduced in the 1990s and defined as a "non-digestible food ingredient that beneficially affects the host by selectively stimulating the growth and/or activity of one or a limited number of bacteria already resident in the colon" [74]. This definition was first updated to state "selectively fermented ingredients that result in specific changes, in the composition and/or activity of the gastrointestinal microbiota, thus conferring benefit(s) upon host health" [75]. Recently, however, the prebiotic concept has been more broadly defined as "a substrate that is selectively utilized by host microorganisms conferring a health benefit" thus including non-carbohydrates as well as applications to non-GIT body sites and hence non-food substances [76]. Due to the rather low amounts in the Western-type diet, prebiotics are regarded as a sub-group of functional ingredients that can be added to foods such as yogurt, bread, cereals, biscuits, ice cream, etc. [75]. Prebiotic and other oligosaccharides in the food are metabolized by probiotic [77] and some commensal bacteria for example the prominent Bacteriodetes [78]. However, to be approved as a prebiotic destined as in the present case for the GIT, a candidate is expected also to fulfill the following criteria [79], i) be resistant to gastric $\mathrm{pH}$, non-digestible by enzymes of the mammalian host, and not adsorbed in the GIT, ii) be fermentable by the GIT microbiota and prominently by probiotic bacteria, and iii) selectively stimulate growth and/or activity of intestinal bacteria correlated with health and well-being. Notably, certain commensal bacteria show specific beneficial behavior, including adhesion to the GIT epithelium, and some may be considered as prospective probiotics [24]. Similarly, results of in vitro studies have disclosed carbohydrate sources and other beneficial compounds which may be categorized as candidate prebiotics, but for which the validation by effect in human intervention trials has not been undertaken. Claims of status as prebiotics always require that health benefits have been achieved in controlled studies in the target host [76].

\subsection{Synbiotics}

Recently, attention has as well been on synbiotics, which are defined as "a mixture of probiotics and prebiotics that beneficially affects the host by improving the survival and implantation of live microbial dietary supplements in the gastrointestinal tract, by selectively stimulating the growth and/or activating the metabolism of one or a limited number of health promoting bacteria, and thus improving host welfare" $[4,27,74]$. The effect of the prebiotic in question should be specific to the probiotic, rendering a competitive advantage over other microbiota members, and the combination should have beneficial effects on the host. With regard to this concept, a few studies have been conducted to confirm effects of specific synbiotics under different perspectives, such as inflammatory bowel disease (IBD), irritable bowel syndrome, or colon cancer $[4,80,81]$.

There are a number of studies, where the impact on the adhesion of probiotics grown on selected carbohydrate sources or other dietary components, has been investigated in vitro and which not necessarily comply with the rigorous definition of synbiotics as a mixture of prebiotics with approved effects in the host and probiotics. These cases are not involving approved synbiotics, but combinations of probiotics and dietary compounds which are of synbiotic-like character. Thus using fructose as a carbon source improved the adhesion to porcine gastric mucin for strains of Lactobacillus delbrueckii subsp. bulgaricus isolated from traditional Mongolian fermented milk products as compared to when grown on lactose, galactose or xylose [82]. Interest has also been on the mechanism of beneficial effects of plant polyphenols on probiotics for gut microbiota and human health, some of which (e.g., tannic acids) were proposed as prebiotics $[83,84]$. Finally, recently the presence of different polyunsaturated fatty acids was shown to reduce survival of lactobacilli, but still to increase their adhesion to intestinal cells [49]. 


\section{Dietary Nutrients-Lactobacillus Interactions Characterized by Adherence and Proteome Analyses}

We focused on adhesion and proteome changes to expand the molecular level insight into the mechanism of approved synbiotics and of candidate synbiotics. It is hypothesized that the utilization of oligosaccharides can modify the abundance of probiotic bacterial proteins important for adhesion to the GIT mucosa. Adhesion to mucin or HT-29 cells was assayed essentially according to the method based on labelling of bacteria with a fluorophore, allowing quantification of adhered cells [51] as reported for L. acidophilus NCFM [44,45,85] (refer to Section 4.1).

Lactobacillus acidophilus NCFM grown on different carbon sources, including approved and emerging prebiotics, and using glucose as reference, demonstrated a connection between the in vitro adhesion capacity to a mucin coating or a confluent HT-29 cell layer, respectively, (Table 1) and relative abundancy changes in bacterial proteomes (Table 2) $[44,45,85]$. The carbon sources included raffinose [44], fructooligosaccharides (FOS), galactooligosaccharides (GOS), lactulose, cellobiose, melibiose, palatinose, trehalose, and polydextrose [45]. Moreover, glucose media were supplemented with either mucin $[45,86]$ or one of four plant polyphenols, resveratrol, tannic acid, caffeic acid, and ferulic acid [85]. In the set-up applied to assess adhesion, $2-3 \%$ of the bacterial cells from the reference culture on glucose adhered, while growth on various carbon sources and supplementation with mucin or plant polyphenols stimulated adhesion to reach $11 \%$ of the added cells. Notably, the levels of growth and adhesion to mucin or HT-29 cells layers were not directly coupled [44,45]. Thus L. acidophilus NCFM growth was stimulated on some and slowed by other media compared to glucose, moreover several carbon sources, GOS, lactulose, melibiose, palatinose, trehalose of which GOS and lactulose are approved as prebiotics [76], did not lead to improved adhesion [45]. The bacteria grew slowly on raffinose and cellobiose, but still exhibited elevated adherence to both mucin and HT-29 cells. Similar effects were found with polydextrose and FOS as carbon sources. Growth was stimulated by supplementation with mucin and also accompanied by improved adhesion, albeit only to HT-29 cells [45]. The effect on adhesion of selected plant polyphenols depended on their concentration in the growth media [45] (Table 1). Another study reported that wine polyphenols increased adhesion of probiotics to Caco-2 cells [86].

Table 1. Change in adhesive capacity onto mucin coating and HT-29 cells, respectively, of Lactobacillus acidophilus NCFM grown on different carbon sources and supplements as compared to growth on glucose.

\begin{tabular}{|c|c|c|}
\hline Carbon Source $(1 \%) /$ Supplementation & $\begin{array}{c}\text { Mucin }^{\mathrm{d}} \\
\text { (Fold-Increase) }\end{array}$ & $\begin{array}{c}\text { HT-29 d } \\
\text { (Fold-Increase) }\end{array}$ \\
\hline Raffinose $^{\text {a }}$ & $3(p<0.0001)$ & $3(p<0.0001)$ \\
\hline Cellobiose $^{b}$ & $2.5(p<0.05)$ & $2.5(p<0.05)$ \\
\hline Polydextrose $^{b}$ & $3(p<0.05)$ & $2(p<0.05)$ \\
\hline FOS $^{b}$ & n.d. & $2(p<0.05)$ \\
\hline Glucose/mucin $(0.1 \%)^{b}$ & n.d. & $2(p<0.05)$ \\
\hline Glucose/resveratrol $^{\mathrm{c}}$ & $2.3(p<0.01)(100 \mu \mathrm{g} / \mathrm{mL})$ & $\begin{array}{c}1.4(p<0.01)(100 \mu \mathrm{g} / \mathrm{mL}) \\
3.0(p<0.001)(250 \mu \mathrm{g} / \mathrm{mL})\end{array}$ \\
\hline Glucose/tannic acid $^{c}$ & $0.4(p<0.001)(250 \mu \mathrm{g} / \mathrm{mL})$ & $5.0(p<0.001)(100 \mu \mathrm{g} / \mathrm{mL})$ \\
\hline Glucose/caffeic acid $^{c}$ & $1.3(p<0.05)(250 \mu \mathrm{g} / \mathrm{mL})$ & n.d. \\
\hline Glucose/ferulic acid ${ }^{\mathrm{c}}$ & $\begin{array}{c}0.8(p<0.01)(100 \mu \mathrm{g} / \mathrm{mL}) \\
1.9(p<0.001)(250 \mu \mathrm{g} / \mathrm{mL}) \\
1.2(p<0.001)(500 \mu \mathrm{g} / \mathrm{mL})\end{array}$ & $1.4(p<0.001)(250 \mu \mathrm{g} / \mathrm{mL})$ \\
\hline
\end{tabular}

References: ${ }^{\mathrm{a}}$ [44], ${ }^{\mathrm{b}}$ [45], ${ }^{\mathrm{c}}$ [85]. ${ }^{\mathrm{d}}$ Statistic significance level of increased adhesion compared to growth on glucose as control and concentration of polyphenol during growth are both given in parentheses. n.d. = not detected. 
Table 2. Surface proteins showing relative abundancy changes in Lactobacillus acidophilus NCFM with increased adhesive capacity.

\begin{tabular}{|c|c|c|c|c|c|c|c|c|}
\hline \multirow{2}{*}{ Protein Name } & \multirow{2}{*}{$\begin{array}{l}\text { Accession } \\
\text { Number }\end{array}$} & \multicolumn{7}{|c|}{ Carbon Source and Protein Fold-Change } \\
\hline & & $\mathbf{R a}^{\mathbf{a}}$ & $\mathrm{Ce}^{\mathrm{b}}$ & $\mathrm{Mu}^{\mathrm{b}}$ & $\operatorname{Re}^{c}$ & $\mathrm{TA}^{\mathrm{c}}$ & $\mathrm{CA}^{\mathrm{c}}$ & FA $^{\mathrm{c}}$ \\
\hline $\begin{array}{l}\text { Phosphate starvation inducible protein } \\
\text { stress-related }\end{array}$ & YP_193579 & +4.4 & +4.4 & & & & & \\
\hline Thermostable pullulanase & YP_194553 & +2.3 & +3.5 & & & & & \\
\hline Elongation factor $\mathrm{G}^{\mathrm{M}}$ & YP_193213 & +2.1 & +2.4 & -3.5 & & -2.0 & & \\
\hline 50S Ribosomal protein L7/L12 & YP_193293 & & & & +2.0 & & & \\
\hline Pyruvate kinase $^{\mathrm{M}}$ & YP_193840 & & -1.7 & +1.9 & +2.1 & & & -1.6 \\
\hline Fructose-bis-phosphate aldolase ${ }^{\mathrm{M}}$ & YP_194445 & & & +1.8 & & & & \\
\hline Elongation factor $\mathrm{P}$ & YP_194511 & & & & +1.7 & & -1.7 & \\
\hline 50S Ribosomal protein L22 & YP_193220 & & & & +1.6 & & & \\
\hline Glutamyl tRNA synthase & YP_193270 & & & & & & +1.5 & \\
\hline Hypothetical protein LBA1769 & YP_194608 & & & & +1.4 & & & \\
\hline Aminopeptidase & YP_104682 & & & & & +1.4 & & \\
\hline S-layer Protein & YP_193101 & +1.3 & & & & & & \\
\hline Glycoprotein endopeptidase & YP_193310 & -1.4 & & & & +1.3 & & \\
\hline 6-phophofructokinase ${ }^{\mathrm{M}}$ & YP_193839 & & & & -1.4 & & & \\
\hline Phosphoglycerate kinase ${ }^{\mathrm{M}}$ & YP_193605 & -1.4 & & -3.1 & & & & \\
\hline Molecular chaperone GroEL ${ }^{\mathrm{M}}$ & YP_193328 & -1.5 & & & & & & \\
\hline D-lactate dehydrogenase & YP_192990 & & & & & & -1.5 & \\
\hline 50S Ribosomal protein L10 & YP_193292 & -1.6 & & & & & & \\
\hline Trigger factor ${ }^{M}$ & YP_193738 & & & & & & & -1.7 \\
\hline 50S Ribosomal protein L1 & YP_193283 & -1.8 & & & & & & \\
\hline ATP synthase FOF1 subunit alpha & YP_193673 & -1.8 & & & & & & \\
\hline Oligoribonuclease & YP_193337 & & & & & & & -1.8 \\
\hline Elongation factor $\mathrm{Tu}^{\mathrm{M}}$ & YP_193737 & -1.8 & & & & & -1.8 & \\
\hline Lysine tRNA ligase & YP_193205 & & & & & & -1.9 & \\
\hline L-lactate dehydrogenase & YP_193195 & & & & & & & -1.6 \\
\hline Elongation factor Ts & YP_194131 & & -2.0 & & & & & \\
\hline Triose phosphate isomerase ${ }^{\mathrm{M}}$ & YP_193606 & -2.0 & & & & & -2.0 & -1.7 \\
\hline $\begin{array}{l}\text { Manganese-dependent inorganic } \\
\text { pyrophosphatase }\end{array}$ & YP_194000 & -1.5 & & -2.1 & & -1.5 & & -1.5 \\
\hline Aspartate tRNA ligase & YP_193821 & & & & & & -2.2 & \\
\hline Adenylosuccinate synthase & YP_194721 & & & -2.3 & -1.5 & & -1.5 & \\
\hline 30S Ribosomal protein S1 M & YP_193850 & & & -2.3 & & & -1.8 & -1.7 \\
\hline Ribonucleoside triphosphate reductase & YP_192977 & & & -2.3 & & & & \\
\hline $\begin{array}{l}\text { Glyceraldehyde-3-p dehydrogenase } \\
\text { (GAPDH) }\end{array}$ & YP_193579 & $\begin{array}{l}-2.4 \\
-1.9 \\
-1.6\end{array}$ & $\begin{array}{l}-2.0 \\
-1.5\end{array}$ & & $\begin{array}{l}-2.0 \\
-1.6\end{array}$ & & & \\
\hline $\begin{array}{l}\text { BipAEFTU family GTP-binding } \\
\text { protein } \mathrm{M}\end{array}$ & YP_193724 & & & -2.7 & & & & \\
\hline
\end{tabular}

${ }^{\mathrm{M}}$ Reported moonlighting proteins. References: ${ }^{\mathrm{a}}$ [44], ${ }^{\mathrm{b}}$ [45], ${ }^{\mathrm{c}}$ [85]. Carbon source, Ra = raffinose; Ce = cellobiose; $\mathrm{Mu}=$ glucose supplemented with mucin; $\mathrm{Re}=$ glucose in presence of resveratrol; $\mathrm{TA}=$ glucose in presence of tannic acid; $\mathrm{CA}=$ glucose in the presence of caffeic acid; $\mathrm{FA}=$ glucose in presence of ferulic acid. 
The relative protein abundancy changes were determined by comparative 2-DE for whole cell or surface proteomes of L. acidophilus NCFM cultured with the different carbon sources and supplements as compared to glucose followed by protein identification by in-gel digestion and mass spectrometry for selected spots undergoing relative intensity changes $[44,45,85]$. The findings by this straightforward procedure indicated selected stimulation of the occurrence of potential protein factors promoting adhesion. Some proteins of the surface proteome increased in relative abundancy by up to 4.4 fold, while others decreased by as much as 2.7 fold (Table 2). Notably, depending on the carbon source, a number of moonlighting proteins, elongation factor $G$, pyruvate kinase and fructose bis-phosphate aldolase increased in relative abundancy, whereas other moonlighting proteins decreased, including the well-known glyceraldehyde-3-phosphate dehydrogenase (GAPDH), triose phosphate isomerase, elongation factor $\mathrm{Tu}$, phosphoglycerate kinase, molecular chaperone GroEL, and 6-phosphofructo kinase. Elongation factor $G$ increased 2.1 and 2.4 fold with raffinose [44] and cellobiose [45], respectively, as carbon source, and decreased 3.5 and 2.0 fold when grown on glucose in the presence of either mucin or tannic acid (Table 2) $[45,85]$. Pyruvate kinase increased in the presence of mucin or resveratrol, but decreased when grown on glucose in the presence of ferulic acid or with cellobiose as carbon source [85] (Table 2). Thus effects on known moonlighting proteins can vary, and although it a priori may be expected that increased adhesion would be accompanied by increase in amounts of the affected moonlighting proteins, this was observed not always to be the case (Table 2). Indeed, the complexity is larger than analyzed for here as is also reflected by the fact that some proteins of altered abundancy occur in different proteoforms, for which knowledge is lacking on the eventual posttranslational modifications. For example, proteoforms originating from the same GADPH gene are seen by 2-DE surface proteome analysis of a small spot-train with a range of pI values and constant molecular mass $[44,45,85]$.

Growth of L. acidophilus NCFM on lactulose (an approved prebiotic), raffinose or cellobiose elicited abundancy changes in the whole cell proteome indicating changes in the uptake and metabolism of these carbohydrates $[44,87,88]$. On cellobiose, this included several moonlighting proteins, phosphoglycerate kinase, triose phosphate isomerase, and GADPH as well as surface layer protein [88]. A human intervention study demonstrated the putative synbiotic of L. acidophilus NCFM and cellobiose to increase the abundance of lactobacilli, bifidobacteria, and branched chain fatty acids without affecting the human gut bacterial diversity and the amount of short chain fatty acids [89]. By contrast, however, in in vitro colon simulator experiments, production of the beneficial short chain fatty acids and the count of L. acidophilus NCFM increased for synbiotics candidates containing cellobiose or raffinose [90]. Investigation of the emerging prebiotic raffinose, for which a rich source is side streams in soy protein production, was motivated by the lack of $\alpha$-galactosidase in the human GIT and demonstrated to increase adhesion of L. acidophilus NCFM on both mucin and HT-29 cells by 3 fold (Table 1; Figure 4) [44].

\section{Conclusions and Future Perspectives}

Understanding of the possible mechanisms by which food components influence on adhesion of probiotic bacteria in vivo can benefit from thorough investigation at the molecular level in vitro. The present mini-review provides insights into the relationship between surface-proteins, carbon source and adhesion ability of probiotic bacteria with emphasis on L. acidophilus NCFM. The findings demonstrate a connection between dietary nutrients, probiotic adhesion and protein profiles. Although this set-up is an oversimplification of the in vivo situation, which likely has distinct uncovered characteristics, the in vitro experiments illustrate both the complexity and that knowledge is lacking on molecular details of GIT adhesion and its potential implications for the host. The described reactions of L. acidophilus NCFM to growth conditions (carbon source and supplementation with mucin or plant polyphenols) contribute to decoding the intricate interplay of probiotics, diet and host in particular with relevance for synbiotics. The recognition of beneficial health effects elicited by combinations of microorganisms and dietary components continues to include novel systems which 
deserve to be explored at the molecular level by using proteomics strategies. It is for example realized recently that different bacterial $\beta$-glucans stimulate adhesion [91,92]. Additionally, molecular level characterization will be relevant for the effect of well-known beneficial components such as cereal $\beta$-glucans as well as other dietary fibers and their oligosaccharide degradation products. Still however, only clinical studies will be able to provide the basis for accepting the new dietary nutrients as prebiotic/synbiotics.

Author Contributions: The authors together conceived the contents. H.U.C. wrote the initial draft and B.S. completed the manuscript.

Acknowledgments: The work was supported by a PhD scholarship to H.U.C. from the Republic of Turkey, Ministry of National Education, the Danish Council for Strategic Research, committee for Health, Food and Welfare, the Danish Council for Independent Research I Natural Sciences and the Center for Advanced Food Studies.

Conflicts of Interest: The authors declare no conflict of interest.

\section{References}

1. Roberfroid, M.B. A European consensus of scientific concepts of functional foods. Nutrition 2000, 16, 689-691. [CrossRef]

2. Voreades, N.; Kozil, A.; Weir, T.L. Diet and the development of the human intestinal microbiome. Front. Microbiol. 2014, 5, 494. [CrossRef] [PubMed]

3. Bron, P.A.; Kleerebezeem, M.; Brummer, R.-J.; Cani, P.D.; Mercenier, A.; MacDonald, T.T.; Garcia-Ródenas, C.L.; Wells, J.M. Can probiotics modulate human disease by impacting intestinal barrier function? Br. J. Nutr. 2017, 117, 93-107. [CrossRef] [PubMed]

4. Markowiak, P.; Slizewska, K. Effects of probiotics, prebiotics, and synbiotics on human health. Nutrients 2017, 9, 1021. [CrossRef] [PubMed]

5. Arena, M.P.; Capozzi, V.; Spano, G.; Fiocco, D. The potential of lactic acid bacteria to colonize bionic and abiotic surfaces and the investigation of their interactions. Appl. Microbiol. Biotechnol. 2017, 101, 2641-2657. [CrossRef] [PubMed]

6. Deepika, G.; Charalampopoulos, D. Surface and adhesion properties of Lactobacilli. Adv. Appl. Microbiol. 2010, 40, 127-152. [CrossRef]

7. Buck, B.; Altermann, E.; Svingerud, T.; Klaenhammer, T.R. Functional analysis of putative adhesion factors in Lactobacillus acidophilus NCFM. Appl. Environ. Microbiol. 2005, 71, 8344-8351. [CrossRef] [PubMed]

8. O'Flaherty, S.J.; Klaenhammer, T.R. Functional and phenotypic characterization of a protein from L. acidophilus involved in cell morphology, stress tolerance and adhesions to intestinal cells. Microbiology 2010, 156, 3360-3367. [CrossRef] [PubMed]

9. Deplancke, B.; Gaskins, H.R. Microbial modulation of innate defense: Goblet cells and the intestinal mucus layer. Am. J. Clin. Nutr. 2001, 73, 1131S-1141S. [CrossRef] [PubMed]

10. Johnson, B.R.; O’Flaherty, S.; Goh, Y.J.; Carroll, I.; Barrangou, R.; Klaenhammer, T.R. The S-layer associated serine protease homologue PrtX impacts cell surface-mediated microbe-host interactions of Lactobacillus acidophilus NCFM. Front. Microbiol. 2017, 8, 1185. [CrossRef] [PubMed]

11. Johnson, B.; Selle, K.; O'Flaherty, S.; Goh, Y.J.; Klaenhammer, T. Identification of extracellular surface-layer associated proteins in Lactobacillus acidophilus NCFM. Microbiology 2013, 159, 2269-2282. [CrossRef] [PubMed]

12. Amenyogbe, N.; Kollmann, T.R.; Ben-Othman, R. Early-life host-microbiome interface: The key frontier for immune development. Front. Pediatr. 2017, 5, 111. [CrossRef] [PubMed]

13. Park, W. Gut microbiomes and their metabolites shape human and animal health. J. Microbiol. 2018, 56, 151-153. [CrossRef] [PubMed]

14. Bansil, R.; Turner, B.S. Mucin structure, aggregation, physiological functions and biomedical applications. Curr. Opin. Colloid Interface Sci. 2006, 11, 164-170. [CrossRef]

15. Van Tassell, M.L.; Miller, M.J. Lactobacillus adhesion to mucus. Nutrients 2011, 3, 613-636. [CrossRef] [PubMed] 
16. Fukuda, K. Is it feasible to control pathogen infection by competitive binding of probiotics to the host? Virulence 2017, 8, 1502-1505. [CrossRef] [PubMed]

17. Etzold, S.; Juge, N. Structural insights into bacterial recognition of intestinal mucins. Curr. Opin. Struct. Biol. 2014, 28, 23-31. [CrossRef] [PubMed]

18. Tailford, L.E.; Crost, E.H.; Kavanaugh, D.; Juge, N. Mucin glycan foraging in the human gut microbiome. Front. Genet. 2015, 6, 81. [CrossRef] [PubMed]

19. Bäckström, M.; Ambort, D.; Thomsson, E.; Johansson, M.E.V.; Hansson, G.C. Increased understanding of the biochemistry and biosynthesis of MUC2 and other gel-forming mucins through the recombinant expression of their protein domains. Mol. Biotechnol. 2013, 54, 250-256. [CrossRef] [PubMed]

20. Slover, C.M.; Danziger, L. Lactobacillus: A review. Clin. Microbiol. Newsl. 2008, 30, 23-27. [CrossRef]

21. Madigan, M.T.; Martinko, J.M.; Dunlap, P.V.; Clark, D.P. Bacteria: Gram-positive and other bacteria. In Brock: Biology of Microorganisms; Madigan, M.T., Martinko, J.M., Dunlap, P.V., Clark, D.P., Eds.; Pearson Benjamin Cummings: San Francisco, CA, USA, 2009; pp. 446-486. ISBN 978-3-319-48325-2.

22. Sanders, M.E. How do we know when something called "probiotic" is really a probiotic? A guideline for consumers and health care professionals. Funct. Food Rev. 2009, 1, 3-12. [CrossRef]

23. Azcarate-Peril, M.Q.A.; Altermann, E.; Goh, Y.J.; Tallon, R.; Sanozky-Dawes, R.B.; Pfeiler, E.A.; O’Flaherty, S.; Buck, B.L.; Dobson, A.; Duong, T.; et al. Analysis of the genome sequence of Lactobacillus gasseri ATCC 33323 reveals the molecular basis of an autochthonous intestinal organism. Appl. Environ. Microbiol. 2008, 74, 4610-4625. [CrossRef] [PubMed]

24. Hill, C.; Guarner, F.; Reid, G.; Gibson, G.R.; Merenstein, D.J.; Pot, B.; Morelli, L.; Canani, R.B.; Flint, H.J.; Salminen, S.; et al. Expert consensus document: The International Scientific Association for Probiotics and Prebiotics consensus statement on the scope and appropriate use of the term probiotic. Nat. Rev. Gastroenterol. Hepatol. 2014, 11, 506-514. [CrossRef] [PubMed]

25. Anjum, N.; Maqsood, S.; Masud, T.; Ahmad, A.; Sohail, A.; Momin, A. Lactobacillus acidophilus: Charcaterization of the species and application in food production. Crit. Rev. Food Sci. Nutr. 2014, 54, 1241-1251. [CrossRef] [PubMed]

26. Huang, S.; Vignolles, M.-L.; Chen, X.D.; Le Loir, Y.; Jan, G.; Schuck, P.; Jeantet, R. Spray drying of probiotics and other food-grade bacteria: A review. Trends Food Sci. Technol. 2017, 63, 1-17. [CrossRef]

27. Collins, M.D.; Gibson, G.R. Probiotics, prebiotics, and synbiotics: Approaches for modulating the microbial ecology of the gut. Am. J. Clin. Nutr. 1999, 69, 1052S-1057S. [CrossRef] [PubMed]

28. Ouwehand, A.C.; Salminen, S.; Isolauri, E. Probiotics: An overview of beneficial effects. Antonie van Leeuwenhoek 2002, 82, 279-289. [CrossRef] [PubMed]

29. Siciliano, R.A.; Mazzeo, M.F. Molecular mechanisms of probiotic action: A proteomic perspective. Curr. Opin. Microbiol. 2012, 15, 390-396. [CrossRef] [PubMed]

30. Muyyarikkandy, M.S.; Amalaradjou, M.A. Lactobacillus bulgaricus, Lactobacillus rhamnosus and Lactobacillus paracasei attenuate Salmonella enteritidis, Salmonella Heidelberg and Salmonella typhimurium colonization and virulence gene expression in vitro. Int. J. Mol. Sci. 2017, 18, 2381. [CrossRef] [PubMed]

31. Tan, Y.; Leonhard, M.; Moser, D.; Schneider-Stickler, B. Inhibition activity of Lactobacilli supernatant against fungal-bacterial multispecies biofilm on silicone. Microb. Pathog. 2017, 113, 197-201. [CrossRef] [PubMed]

32. Sánchez, B.; López, P.; González-Rodrígez, I.; Suárez, A.; Margolles, A.; Urdaci, M.C. A flagellin-producing Lactococcus strain: Interaction with mucin and enteropathogens. FEMS Microbiol. 2011, 318, 101-107. [CrossRef] [PubMed]

33. Son, S.-H.; Jeon, H.-L.; Yang, S.-J.; Lee, N.-K.; Paik, H.-D. In vitro characterization of Lactobacillus brevis KU15006, an isolate from kimchi, reveals anti-adhesion activity against foodborne pathogens and antidiabetic properties. Microb. Pathog. 2017, 112, 135-141. [CrossRef] [PubMed]

34. Buntin, N.; de Vos, W.M.; Hongpattarakare, T. Variation of mucin adhesion, cell surface characteristics, and molecular mechanisms among Lactobacillus plantarum isolated from different habitats. Appl. Microbiol. Biotechnol. 2017, 101, 7663-7674. [CrossRef] [PubMed]

35. Lehri, B.; Seddon, A.M.; Karlyshev, A.V. Lactobacillus fermentum 3872 as a potential tool for combatting Campylobacter jejuni infections. Virulence 2017, 8, 1753-1760. [CrossRef] [PubMed] 
36. Cremon, C.; Guglielmetti, S.; Gargari, G.; Taverniti, V.; Castellazzi, A.M.; Valsecchi, C.; Tagliacarne, C.; Fiore, W.; Bellini, M.; Bertani, L.; et al. Effect of Lactobacillus paracasei CNCM I-1572 on symptoms, gut microbiota, short chain fatty acids, and immune activation in patients with irritable bowel syndrome: A pilot randomized clinical trial. United European Gastroenterol. J. 2018, 6, 604-613. [CrossRef] [PubMed]

37. Madden, J.A.J.; Hunter, J.O. A review of the role of the gut microflora in irritable bowel syndrome and the effects of probiotics. Br. J. Nutr. 2002, 88, s67-s72. [CrossRef] [PubMed]

38. Hempel, S.; Newberry, S.J.; Maher, A.R.; Wang, Z.; Miles, J.N.V.; Shanman, R.; Johnsen, B.; Shekelle, P.G. Probiotics for the prevention and treatment of antibiotic-associated diarrhea. JAMA 2012, 307, 1959-1969. [CrossRef] [PubMed]

39. Pajarillo, E.A.B.; Kim, S.H.; Valeriano, V.D.; Lee, J.Y.; Kang, D.-K. Proteomic view of the crosstalk between Lactobacillus mucosae and intestinal epithelial cells in co-culture revealed by Q Exactive-based quantitative proteomics. Front. Microbiol. 2017, 8, 2459. [CrossRef] [PubMed]

40. Klotz, C.; O'Flaherty, S.; Goh, Y.J.; Barrangou, R. Investigating the effects of growth phase on the surface-layer associated proteome of Lactobacillus acidophilus using quantitative proteomics. Front. Microbiol. 2017, 8, 2174. [CrossRef] [PubMed]

41. Van de Guchte, M.; Chaze, T.; Jan, G.; Mistou, M.-Y. Properties of probiotic bacteria explored by proteomic approaches. Curr. Opin. Microbiol. 2012, 15, 381-389. [CrossRef] [PubMed]

42. Celebioglu, H.U.; Svensson, B. Exo- and surface proteomes of the probiotic bacterium Lactobacillus acidophilus NCFM. Proteomics 2017, 17, 1700019. [CrossRef] [PubMed]

43. Ashida, N.; Yanagihara, S.; Shinoda, T.; Yamamoto, N. Characterization of adhesive molecule with affinity for Caco-2 cells in Lactobacillus acidophilus by proteome analysis. J. Biosci. Bioeng. 2011, 112, 333-337. [CrossRef] [PubMed]

44. Celebioglu, H.U.; Ejby, M.; Majumder, A.; Købler, C.; Goh, Y.J.; Thorsen, K.; Schmidt, B.; O’Flaherty, S.; Abou Hachem, M.; Lahtinen, S.J.; et al. Differential proteome and cellular adhesion analyses of the probiotic bacterium Lactobacillus acidophilus NCFM grown on raffinose-An emerging prebiotic. Proteomics 2016, 16, 1361-1375. [CrossRef] [PubMed]

45. Celebioglu, H.U.; Olesen, S.V.; Prehn, K.; Lahtinen, S.J.; Brix, S.; Abou Hachem, M.; Svensson, B. Mucin- and carbohydrate-stimulated adhesion and subproteome changes of the probiotic bacterium Lactobacillus acidophilus NCFM. J. Proteomics 2017, 163, 102-110. [CrossRef] [PubMed]

46. Espino, E.; Koskenniemi, K.; Mato-Rodriguez, L.; Nyman, T.A.; Reunanen, J.; Koponen, J.; Ohman, T.; Siljamaki, P.; Alatossava, T.; Varmanen, P.; et al. Uncovering surface-exposed antigens of Lactobacillus rhamnosus by cell shaving proteomics and two-dimensional immunoblotting. J. Proteome Res. 2015, 14, 1010-1024. [CrossRef] [PubMed]

47. Johnson, B.R.; Hymes, J.; Sanozky-Dawnes, R.; Henriksen, E.D.; Barrangou, R.; Klaenhammer, T.R. Conserved S-layer-associated proteins revealed by exoproteomic survey of S-layer-forming lactobacilli. Appl. Environ. Microbiol. 2016, 82, 134-145. [CrossRef] [PubMed]

48. Do Carmo, F.L.R.; Rabah, H.; Huang, S.; Gaucher, F.; Deplanche, M.; Dutertre, S.; Jardin, J.; Le Loir, Y.; Azevedo, V.; Jan, G. Propionibacterium freudenreichii surface protein SlpB is involved in adhesion to intestinal HT-29 cells. Front. Microbiol. 2017, 8, 1033. [CrossRef] [PubMed]

49. Bentley-Hewitt, K.L.; Narbad, A.; Majsak-Newman, G.; Philo, M.R.; Lund, E.K. Lactobacilli survival and adhesion to colonic epithelial cell lines is dependent on long chain fatty acid exposure. Eur. J. Lipid Sci. Technol. 2017, 119, 1700062. [CrossRef]

50. Wasko, A.T.; Polak-Berecka, M.; Paduch, R.; Józwiak, K. The effect of moonlighting proteins on the adhesion and aggregation ability of Lactobacillus helveticus. Anaerobe 2014, 30, 161-168. [CrossRef] [PubMed]

51. Izquierdo, E.; Horvatovich, P.; Machioni, E.; Aoude-Werner, D.; Sanz, Y.; Ennahar, S. 2-DE and MS analysis of key proteins in the adhesion of Lactobacillus plantarum, a first step toward early selection of probiotics based on bacterial biomarkers. Electrophoresis 2009, 30, 949-956. [CrossRef] [PubMed]

52. Leteurtre, T.; Gouyer, V.; Rousseau, K.; Moreau, O.; Barbat, A.; Swallow, D.; Lesuffleur, T. Differential mucin expression in colon carcinoma HT-29 clones with variable resistance to 5-fluorouracil and methotrexate. Biol. Cell 2004, 96, 145-151. [CrossRef] [PubMed]

53. Pinto, M.; Robineleon, S.; Appay, M.D.; Kedinger, M.; Triadou, N.; Dussaulx, E.; Lacroix, B.; Simonassmann, P.; Haffen, K.; Fogh, J.; et al. Enterocyte-like differentiation and polarization of the human-colon carcinoma cell-line Caco-2 in culture. Biol. Cell 1983, 47, 323-340. 
54. Spacova, I.; Lievens, E.; Verhoeven, T.; Steenackers, H.; Vanderleyden, J.; Lebeer, S.; Petrova, M.I. Expression of fluorescent proteins in Lactobacillus rhamnosus to study host-microbe and microbe-microbe interactions. Microb. Biotechnol. 2018, 11, 317-331. [CrossRef] [PubMed]

55. Patel, D.K.; Shah, K.R.; Pappachan, A.; Gupta, S.; Singh, D.D. Cloning, expression and characterisation of mucin binding GAPDH from Lactobacillus acidophilus. Int. J. Biol. Macromol. 2016, 91, 338-346. [CrossRef] [PubMed]

56. Bautista-Gallego, J.; Arroyo-López, F.N.; Rantsiou, K.; Jiménez-Díaz, R.; Garrido-Fernández, A.; Cocolin, L. Screening of lactic acid bacteria isolated from fermented table olives with probiotic potential. Food Res. Intl. 2013, 50, 135-142. [CrossRef]

57. Campaniello, D.; Speranza, B.; Petruzzi, L.; Bevilacqua, A.; Corbo, M.R. How to routinely assess transition, adhesion and survival of probiotics into the gut: A case study of propionibacteria. Int. J. Food Sci. Technol. 2018, 53, 484-490. [CrossRef]

58. Bujnakova, D.; Kmet, V. Aggregation of animal Lactobacilli with O157 enterohemorrhagic Escherichia coli. J. Vet. Med. Ser. B 2002, 49, 152-154. [CrossRef]

59. Goh, Y.J.; Klaenhammer, T.R. Functional roles of aggregation-promoting-like factor in stress tolerance and adherence of Lactobacillus acidophilus NCFM. Appl. Environ. Microbiol. 2010, 76, 5005-5012. [CrossRef] [PubMed]

60. Hymes, J.P.; Johnson, B.R.; Barrangou, R.; Klaenhammer, T.R. Functional analysis of an S-layer associated fibronectin-binding protein in Lactobacillus acidophilus NCFM. Appl. Environ. Microbiol. 2016, 82, 2676-2685. [CrossRef] [PubMed]

61. Bengoa, A.A.; Zavala, L.; Carasi, P.; Trejo, S.A.; Bronsoms, S.; de los Angeles Serradell, M.; Garrote, G.L.; Abraham, A.G. Simulated gastrointestinal conditions increase adhesion ability of Lactobacillus paracasei strains isolated from kefir to Caco-2 cells and mucin. Food Res. Intl. 2018, 103, 462-467. [CrossRef] [PubMed]

62. Boekhorst, J.; Helmer, Q.; Kleerebezem, M.; Siezen, R.J. Comparative analysis of proteins with a mucus-binding domain found exclusively in lactic acid bacteria. Microbiology 2006, 152, 273-280. [CrossRef] [PubMed]

63. Etzold, S.; Kober, O.L.; MacKenzie, D.A.; Tailford, L.E.; Gunning, A.P.; Walshaw, J.; Hemmings, A.M.; Juge, N. Structural basis for adaptation of lactobacilli to gastrointestinal mucus. Environ. Microbiol. 2014, 16, 888-903. [CrossRef] [PubMed]

64. Hytönen, J.; Hataja, S.; Finne, J. Streptococcus pyogenes glycoprotein-binding strepadhesin activity is mediated by a surface-associated carbohydrate-degrading enzyme, pullulanase. Infect. Immun. 2003, 71, 784-793. [CrossRef] [PubMed]

65. Hytönen, J.; Hataja, S.; Finne, J. Use of flow cytometry for the adhesion analysis of Streptococcus pyogenes mutant strain to epithelial cells: Investigation of the possible role of surface pullulanase and cysteine protease, and the transcriptional regulator Rgg. BMC Microbiol. 2006, 6, 18. [CrossRef] [PubMed]

66. Aryantini, N.P.D.; Kondoh, D.; Nishiyama, K.; Yamamoto, Y.; Mukai, T.; Sujaya, I.N.; Urashima, T.; Fukuda, K. Anchorless cell surface proteins function as laminin-binding adhesins in Lactobacillus rhamnosus FSMM22. FEMS Microbiol. Lett. 2017, 364. [CrossRef] [PubMed]

67. Okochi, M.; Sugita, T.; Asai, Y.; Tanaka, M.; Honda, H. Screening of peptides associated with adhesion and aggregation of Lactobacillus rhamnosus GG in vitro. Biochem. Eng. J. 2017, 128, 178-185. [CrossRef]

68. Kainulainen, V.; Korhonen, T.K. Dancing to another tune-Adhesive moonlighting proteins in bacteria. Biology 2014, 3, 178-204. [CrossRef] [PubMed]

69. Jeffery, C.J. Protein moonlighting: What is it, and why is it important. Phil. Trans. R. Soc. B. $2018,373$. [CrossRef] [PubMed]

70. Gancedo, C.; Flores, C.-L.; Gancedo, J.M. The expanding landscape of moonlighting proteins in yeasts. Micromol. Mol. Biol. Rev. 2016, 80, 765-777. [CrossRef] [PubMed]

71. Mani, M.; Chen, C.; Amblee, V.; Liu, H.; Mathur, T.; Zwicke, G.; Zabad, S.; Patel, B.; Thakkar, J.; Jeffery, C.J. MoonProt: A database for proteins that are known to moonlight. Nucleic Acids Res. 2015, 43, D277-D282. [CrossRef] [PubMed] 
72. Jia, F.-F.; Zhang, L.-J.; Pang, X.-H.; Gu, X.-X.; Abdelazez, A.; Liang, Y.; Sun, S.-R.; Meng, X.-C. Complete genome sequence of bacteriocin-producing Lactobacillus plantarum KLDS1.0391, a probiotic strain with gastrointestinal tract resistance and adhesion to the intestinal epithelial cell. Genomics 2017, 109, 432-437. [CrossRef] [PubMed]

73. Ramiah, K.; van Reenen, C.A.; Dicks, L.M. Surface-bound proteins of Lactobacillus plantarum 423 that contribute to adhesion of Caco-2 cells and their role in competitive exclusion and displacement of Clostridium sporogenes and Enterococcus faecilis. Res. Microbiol. 2008, 159, 470-475. [CrossRef] [PubMed]

74. Gibson, G.R.; Roberfroid, M.B. Dietary modulation of the human colonic microbiota: Introducing the concept of prebiotics. J. Nutr. 1995, 125, 1401-1412. [PubMed]

75. Gibson, G.R.; Probert, H.M.; Van Loo, J.; Rastall, R.A.; Roberfroid, M.B. Dietary modulation of the human colonic microbiota: Updating the concept of prebiotics. Nutr. Res. Rev. 2004, 17, 259-275. [CrossRef] [PubMed]

76. Gibson, G.R.; Hutkins, R.; Sanders, M.E.; Prescott, S.L.; Reimer, R.A.; Salminen, S.J.; Scott, K.; Stanton, C.; Swanson, K.S.; Cani, P.D.; et al. The International Scientific Association for Probiotics and Prebiotics (ISAPP) consensus statement on the definition and scope of prebiotics. Nat. Rev. Gastroenterol. Hepatol. 2017, 14, 491-502. [CrossRef] [PubMed]

77. Goh, Y.J.; Klaenhammer, T.R. Genetic mechanisms of prebiotic oligosaccharide metabolism in probiotic microbes. Ann. Rev. Food Sci. Technol. 2015, 6, 137-156. [CrossRef] [PubMed]

78. Mao, B.; Li, D.; Zhao, J.; Liu, X.; Gu, Z.; Chen, Y.Q.; Zhang, H.; Chen, W. In vitro fermentation of fructooligosaccharides with human gut bacteria. Food Funct. 2015, 6, 947-954. [CrossRef] [PubMed]

79. Gibson, G.R.; Scott, K.P.; Rastall, R.A.; Tuohy, M.M.; Hotchkiss, A.; Dubert-Ferrandon, A.; Garau, M.; Murphy, E.F.; Saulnier, D.; Loh, G.; et al. Dietary prebiotics: Current status and new definition. Food Sci Technol Bull Funct Foods 2010, 7, 1-19. [CrossRef]

80. Kolida, S.; Gibson, G.R. Synbiotics in health and disease. Annu. Rev. Food Sci. Technol. 2011, 2, $373-393$. [CrossRef] [PubMed]

81. Krumbeck, J.A.; Water, J.; Hutkins, R.W. Synbiotics for improved human health: Recent developments, challenges, and opportunities. Annu. Rev. Food. Sci. Technol. 2018, 9, 451-479. [CrossRef] [PubMed]

82. Kimoto-Nira, H.; Yamasaki, S.; Sasaki, K.; Moriya, N.; Takenaka, A.; Suzuki, C. New lactic acid bacterial strains from traditional Mongolian fermented milk products have altered adhesion to porcine gastric mucin depending on the carbon source. Anim. Sci. J. 2015, 86, 325-332. [CrossRef] [PubMed]

83. Cardona, F.; Andrés-Lacueva, C.; Tulipani, S.; Tinahones, F.J.; Queipo-Ortuno, M.I. Benefits of polyphenols on gut microbiota and implications in human health. J. Nutri. Biochem. 2013, 24, 1415-1422. [CrossRef] [PubMed]

84. De Llano, D.G.; Gill-Sanchez, I.; Esteban-Fernande, A.; Ramos, A.M.; Fernandez-Diaz, M.; Cueva, C.; Moreno-Arribas, M.V.; Bartolome, B. Reciprocal beneficial effects between wine polyphenols and probiotics: An exploratory study. Eur. Food Res. Technol. 2017, 243, 531-538. [CrossRef]

85. Celebioglu, H.U.; Delsoglio, M.; Brix, S.; Pessione, E.; Svensson, B. Plant polyphenols stimulate adhesion to intestinal mucosa and induce proteome changes in the probiotic Lactobacillus acidophilus NCFM. Mol. Nutr. Food Res. 2018, 62, 1700638. [CrossRef] [PubMed]

86. Weiss, G.; Jespersen, L. Transcriptional analysis of genes associated with stress and adhesion in Lactobacillus acidophilus NCFM during passage through an in vitro gastrointestinal tract model. J. Mol. Microbiol. Biotechnol. 2010, 18, 206-214. [CrossRef] [PubMed]

87. Majumder, A.; Sultan, A.; Jersie-Christensen, R.R.; Ejby, M.; Schmidt, B.; Lahtinen, S.J.; Jacobsen, S.; Svensson, B. Proteome reference map of Lactobacillus acidophilus NCFM and quantitative proteomics towards understanding the prebiotic action of lactitol. Proteomics 2011, 11, 3470-3481. [CrossRef] [PubMed]

88. Van Zanten, G.C.; Sparding, N.; Majumder, A.; Lahtinen, S.J.; Svensson, B.; Jacobsen, S. The acidic and alkaline differential proteomes of Lactobacillus acidophilus NCFM grown on cellobiose shows up-regulation of two $\beta$-glycoside hydrolases and proteins involved in adherence. BioMed Res. Int. 2015, 2015, 347216. [CrossRef] [PubMed] 
89. Van Zanten, G.; Krych, L.; Röytiö, H.; Forssten, S.; Lahtinen, S.; Al-Soud, W.; Sørensen, S.; Svensson, B.; Jespersen, L.; Jakobsen, M. Synbiotic Lactobacillus acidophilus NCFM and cellobiose does not affect human gut bacterial diversity but increases abundance of lactobacilli, bifidobacteria and branched-chain fatty acids: A randomized, double-blinded cross-over trial. FEMS Microbiol. Ecol. 2014, 90, 225-236. [CrossRef] [PubMed]

90. Van Zanten, G.C.; Knudsen, A.; Röytiö, H.; Forssten, S.; Lawther, M.; Blennow, A.; Lahtinen, S.J.; Jakobsen, M.; Svensson, B.; Jespersen, L. The effect of selected synbiotics on microbial composition and short-chain fatty acid production in a model system of the human colon. PLoS ONE 2012, 7, e47212. [CrossRef] [PubMed]

91. Russo, P.; López, P.; Capozzi, V.; Fernández de Palencia, P.; Duenas, M.T.; Spano, G.; Fiocco, D. Beta-glucans improve growth, viability and colonization of probiotic microorganisms. Int. J. Mol. Sci. 2012, 13, 6026-6039. [CrossRef] [PubMed]

92. Allonsius, C.N.; van den Broek, M.F.L.; De Boeck, I.; Kiekens, S.; Oerlemans, E.F.M.; Kiekens, F.; Foubert, K.; Vandenheuvei, D.; Cos, P.; et al. Interplay between Lactobacillus rhamnosus GG and Candida and the involvement of exopolysaccharides. Microb. Biotechnol. 2017, 10, 1753-1763. [CrossRef] [PubMed]

(C) 2018 by the authors. Licensee MDPI, Basel, Switzerland. This article is an open access article distributed under the terms and conditions of the Creative Commons Attribution (CC BY) license (http:/ / creativecommons.org/licenses/by/4.0/). 